\title{
Overcoming dormancy in seeds of Dietes bicolor (Steud.) Sweet ex Klatt
}

\author{
Thiago Roberto Rezende Borges ${ }^{1}\left(\mathbb{D}\right.$, Maurecilne Lemes da Silva ${ }^{2}$, \\ Givanildo Zildo da Silva ${ }^{1}$ (1), Diego Ismael Rocha ${ }^{3 *}$ (1)
}

\begin{abstract}
${ }^{1}$ Universidade Federal de Jataí, Unidade Acadêmica de Ciências Agrárias, Jataí-GO, Brazil. ${ }^{2}$ Universidade do Estado de Mato Grosso, Faculdade de Ciências Agrárias, Biológicas e da Saúde, Tangará da Serra-MT, Brazil. ${ }^{3}$ Universidade Federal de Viçosa, Departamento de Agronomia, Viçosa-MG, Brazil.
\end{abstract}

\begin{abstract}
Seminiferous propagation of Dietes bicolor is hindered by the probable physical and/or morphophysiological dormancy. The objective was to analyze the efficacy of different methods of overcoming dormancy in D. bicolor seeds to determine a possible pre-germination treatment for the species. Two experiments were conducted: (I) Evaluation of the breaking of physical dormancy, in which the treatments of mechanical scarification were carried using sandpaper \#100; chemical scarification with sulfuric acid $\left(\mathrm{H}_{2} \mathrm{SO}_{4}\right)$ for 5 and 10 minutes and immersion in hot water $\left(70^{\circ} \mathrm{C}\right)$, also, for 5 and 10 minutes, were evaluated. The intact seed was considered a control. (II) Evaluation of morphophysiological dormancy, in which the seeds were submitted to combined treatments of stratification of hot temperature $\left(20-35^{\circ} \mathrm{C}\right)$ and/or cold temperature $\left(9^{\circ} \mathrm{C}\right)$, distributed in periods of 0,1 , and 2 weeks, totalizing 9 treatments. In both experiments, germination percentage $(\mathrm{G})$, germination speed index (GSI), and first count (FC) were determined, using a randomized block design, and evaluated by the Scott-Knott test at $1 \%$ and Dunnett's test at 5\%. The use of $\mathrm{H}_{2} \mathrm{SO}_{4} 10$ minutes induced $42 \%$ germination, $0.52 \mathrm{GSI}$, and $18 \% \mathrm{FC}$, but only FC was significantly different from the control. In the second trial, the treatment that spent only two weeks in hot temperatures $\left(20-35{ }^{\circ} \mathrm{C}\right)$ showed the highest germination $(30 \%)$, compared to the control $(\mathrm{G}=22 \%)$. These results provide relevant information for understanding the physiology of D. bicolor germination, in addition to contributing to the optimization of pre-germination practices for this important ornamental species.
\end{abstract}

Keywords: butterfly iris, chemical scarification, Iridaceae, ornamental monocot, seminiferous propagation.

\section{Resumo}

Superação de dormência em sementes de Dietes bicolor (Steud.) Sweet ex Klatt.

A propagação seminífera de Dietes bicolor é dificultada pela provável dormência física e/ou morfofisiológica. Objetivou-se analisar a eficácia de diferentes métodos de superação de dormência em sementes de D. bicolor a fim de determinar possível tratamento prégerminativo para a espécie. Foram realizados dois experimentos: (I) Avaliação da quebra de dormência física, em que os tratamentos de escarificação mecânica utilizando-se lixa $\mathrm{n}^{\circ} 100$; escarificação química com ácido sulfúrico $\left(\mathrm{H}_{2} \mathrm{SO}_{4}\right)$ por 5 e 10 minutos e imersão em água quente $\left(70^{\circ} \mathrm{C}\right)$, também, em 5 e 10 minutos foram avaliados. A semente intacta foi considerada testemunha. (II) Avaliação da dormência morfofisiológica, no qual as sementes foram submetidas a tratamentos combinados de estratificação de temperaturas quentes $\left(20-35{ }^{\circ} \mathrm{C}\right)$ e/ou temperatura fria $\left(9{ }^{\circ} \mathrm{C}\right)$, distribuídas nos períodos de 0 , 1 e 2 semanas, totalizando 9 tratamentos. Em ambos os experimentos se determinou a porcentagem de germinação (G), índice de velocidade de germinação (IVG) e primeira contagem (PC), utilizando-se o delineamento em blocos casualizados e avaliados pelo teste de Scott-Knott a 1\% e Dunnett à $5 \%$. O uso $\mathrm{H}_{2} \mathrm{SO}_{4}$ por 10 minutos induziu $42 \%$ de germinação, 0,52 de índice de velocidade de germinação e $18 \%$ de primeira contagem, todavia somente PC mostrou-se significativamente distinto em relação à testemunha. No segundo ensaio, o tratamento que passou somente duas semanas em temperatura $\left(20-35^{\circ} \mathrm{C}\right)$ apresentou a maior germinação $(30 \%)$, em relação à testemunha $(\mathrm{G}=22 \%)$. Esses resultados constituem informações relevantes para a compreensão da fisiologia da germinação de $D$. bicolor, além de contribuir com a otimização de práticas pré-germinativas para essa importante espécie ornamental.

Palavras-chave: moreia, escarificação química, Iridaceae, monocotiledônea ornamental, propagação seminífera.

*Corresponding Author: diego.rocha@ufv.br/diegoirocha@gmail.com

https://doi.org/10.1590/2447-536X.v28i1.2410

Received: June 28, 2021 | Accepted: Oct 15, 2021 | Available online: Nov 19, 2021

Licensed by CC BY 4.0 (https://creativecommons.org/licenses/by/4.0/)

Area Editor: Petterson Baptista da Luz 


\section{Introduction}

Floriculture has a growing impact on agriculture. The global production of ornamental plants has grown worldwide, showing potential for expansion (Van Rijswick, 2016). The distinction of the flower market occurs due to the continuous integration of production and logistics technologies as well as the introduction of new species and cultivars into the market (Junqueira and Peetz, 2017). In this context, the Iridaceae species have stood out due to the recognized ornamental importance of these species, because of the beauty of their flowers and leaves, and the large number of species cultivated for this purpose.

Iridaceae is a family of perennial monocots, consisting of about 2,000 species mainly distributed in the Northern Hemisphere, Africa, and Central and South America (Goldblatt et al., 2008b). These species are usually propagated by clumps and have slow vegetative development and low germination rates (Hajyzadeh et al., 2019). Kildisheva et al. (2020) classify seed dormancy in Iridaceae as (I) physiological, in which the seeds absorb water and have embryos with low growth potential, sometimes in combination with a mechanical restriction of the seed; or (II) morphological, in which the seeds absorb water readily; however, the embryos are underdeveloped and require time to grow before germination.

In literature, there is a lack of information about the germination biology of these species. Basic protocols for analyzing seeds starting with dormancy overcoming methods have been established for a small number of species in the family. In addition, different methods have been proposed for overcoming dormancy in these species, since the cause of this germination restriction may vary according to each species (Hajyzadeh et al., 2019). Silva et al. (2017), for example, report that in Belamcanda chinensis (Iridaceae), as well as pre-hydration and removal of the outer seed tegument, alternating temperatures before the germination process assists in better results in overcoming physical and physiological dormancy, making clear the importance of endowing combined treatments. Carta et al. (2016) identified in Romulea, that the consequence of the poorly developed embryo was influenced by inadequate exposure to different temperature levels, and that for its proper growth it is necessary to detect the ideal temperature for the species.

To cause simple non-deep morpho-physiological dormancy breaking, as described by Baskin and Baskin (2014), the use of hot or cold thermal stratification is necessary, while in others it is necessary to use this technique at a given temperature followed by the other. Carta et al. (2014) also ratified in three species of the genus Crocus (Iridaceae), positive performance in the acceleration of growth and development of poorly developed embryos after exposure of their seeds in a heated environment and then to the cold, thus increasing the emission of their radicle, also indicating their requirement for high temperatures to break physiological dormancy.

Dietes bicolor (Steud.) Sweet ex Klatt, popularly known as African iris or butterfly iris, belongs to the family Iridaceae and probably constitutes the most basal old-world member of the tribe Irideae (Goldblatt and Manning, 2008a). It is an ornamental species of increasing commercial value (Ayoub et al., 2018; Menegaes et al., 2020), which can also be used for medicinal purposes as a potential source of natural antibacterial and antifungal agents (Ayoub et al., 2018). Recent studies have shown the effects of plant growth regulators on in vitro germination and development of D. bicolor seedlings, although the germination percentage was low (Silva et al., 2020). Given our little knowledge on the process of germination of $D$. bicolor, this study aimed to identify the type of dormancy (physical and/or physiological) and then evaluate the effects of pre-germination treatments in overcoming dormancy in seeds of this species.

\section{Materials and Methods}

Seeds of $D$. bicolor plants were collected in Jataí

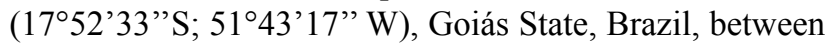
the months of September to October 2019. The seeds were cleaned, that is, impurities and malformed seeds were discarded. Subsequently, the seeds were conditioned in paper bags and kept in a refrigerator $\left(9^{\circ} \mathrm{C}\right)$ for one week before the installation of the experiments.

The present work was divided into two experiments conducted in a randomized block design. The first experiment (I) was conducted to evaluate the breaking of physical dormancy, consisting of six treatments, four blocks of 25 seeds. These were: Control (intact seed) (1); Mechanical scarification in which water sandpaper \#100 was used (2); Chemical scarification with sulfuric acid $\left(\mathrm{H}_{2} \mathrm{SO}_{4}\right)$ done in 5 (3) and 10 minutes (4) and, finally, immersion in hot water $70{ }^{\circ} \mathrm{C}$ performed, also, in 5 (5) and 10 minutes (6). After obtaining each treatment, the seeds were disinfected with commercial $2.0 \%-2.5 \%$ sodium hypochlorite $(\mathrm{NaClO})$ for 20 minutes.

The seeds were sown in transparent acrylic boxes $(11.0 \times 11.0 \times 3.5 \mathrm{~cm})$ on two sheets of blotting paper, duly moistened with 2.5 times the dry mass of the paper. The boxes of each block were packed in plastic bags, to avoid dehydration of the papers, and kept in a germination chamber at $25^{\circ} \mathrm{C}$ and 16 hours photoperiod. The germination percentage $(\mathrm{G})$ was obtained 25 days after the application of treatments. The First Germination Count (FC) was determined when it reached $50 \%+1 \%$ of the final germination. Daily counts were performed during the germination test until stabilization, and with these data, the germination speed index (GSI) was calculated, according to the methodology proposed by Maguire (1962).

In the second experiment, the seeds were disinfected with commercial $\mathrm{NaClO}(2.0 \%-2.5 \%)$ for 20 minutes and then sown between sand in each transparent acrylic box, with 20 seeds per box. The sand substrate used, 100 g per box, was properly autoclaved and moistened to $60 \%$ retention capacity, as prescribed in the Rules for Seed Analysis RAS (Brasil, 2009), and packed in plastic bags to prevent humidity loss. 
After the boxes with seeds were obtained, they were divided into 9 treatments with 3 blocks. The treatments consisted of two stratification temperatures for the seeds: hot temperatures $\left(20-35^{\circ} \mathrm{C}\right)$ and a cold temperature of $9{ }^{\circ} \mathrm{C}$, obtained in a germination chamber. In addition to the stratification temperature, the exposure time for each treatment was distributed over periods of 0,1 , and 2 weeks, with and without alternating temperatures, as shown in Table 1. At the end of each stratification treatment, the seeds were conducted to germination at $25^{\circ} \mathrm{C}$, as described above. After the germination test, $\mathrm{PC}, \mathrm{G}$, and GSI were evaluated as described previously. In both experiments, normal seedlings were counted, as described by Brasil (2009).

Table 1. Seed temperature stratification treatments. Hot temperatures (HT) ranged from $20-35{ }^{\circ} \mathrm{C}$ and cold temperature (CT) was fixed at $9^{\circ} \mathrm{C}$.

\begin{tabular}{|c|c|}
\hline Treatments & Total temperature stratification period \\
\hline Control & -- \\
\hline Cold temperature (CT) & 1 week \\
\hline Hot temperature (HT) & 1 week \\
\hline 1 week CT +1 week HT & 2 weeks \\
\hline 2 weeks CT & 2 weeks \\
\hline 2 weeks HT & 2 weeks \\
\hline 2 weeks CT +1 week HT & 3 weeks \\
\hline 1 week CT +2 weeks HT & 3 weeks \\
\hline 2 weeks CT +2 weeks HT & 4 weeks \\
\hline
\end{tabular}

The data were analyzed through the ANOVA and clustering of means test by Scott-Knott at $5 \%$ probability using the AgroEstat software. In the second experiment, Dunnett at $1 \%$ was also used for comparison of each stratification with the control. For the latter, we used the Rbio software.

\section{Results and Discussion}

The mechanical and chemical scarification treatments used to overcome physical dormancy in $D$. bicolor seeds showed no differences compared to the control treatment regarding germination percentage and germination speed index (Table 2). Only the thermal scarification with immersion of the seeds in water at $70{ }^{\circ} \mathrm{C}$ for 5 and 10 minutes differed from the control with lower values
(0.03 and 0.00 , respectively). Besides not overcoming dormancy, the thermal scarification treatments delayed or inhibited seed germination, and may have led to seed death. According to Floss Júnior et al. (2020) in some plant species, as Lactuca sativa, it is possible to observe the occurrence of thermodormency, a type of dormancy that occurs when the seed is subjected to temperatures above the optimum, in this species above $35^{\circ} \mathrm{C}$, in which the seeds do not germinate even if exposed again to ideal conditions.

However, even though there was no difference in the germination percentage, mechanical scarification and chemical scarification $\left(\mathrm{H}_{2} \mathrm{SO}_{4}\right) 10$ minutes showed higher values ( $14 \%$ and $18 \%$, respectively) of the first count (Table 2). According to Schmidt et al. (2017), this parameter is generally associated with a higher vigor index in the batch related to the treatment.

Table 2. Germination percentage (G), germination speed index (GSI), and first count (FC) of Dietes bicolor seeds submitted to different pre-germination treatments.

\begin{tabular}{|c|c|c|c|}
\hline Treatments & G (\%) & GSI & FC $(\mathbf{\%})$ \\
\hline Control & $27 \mathrm{a}$ & $0.33 \mathrm{a}$ & $4 \mathrm{~b}$ \\
\hline Mechanical scarification & $23 \mathrm{a}$ & $0.32 \mathrm{a}$ & $14 \mathrm{a}$ \\
\hline Chemical scarification $\left(\mathrm{H}_{2} \mathrm{SO}_{4}\right)-5^{\prime}$ & $34 \mathrm{a}$ & $0.44 \mathrm{a}$ & $7 \mathrm{~b}$ \\
\hline Chemical scarification $\left(\mathrm{H}_{2} \mathrm{SO}_{4}\right)-10^{\prime}$ & $42 \mathrm{a}$ & $0.52 \mathrm{a}$ & $18 \mathrm{a}$ \\
\hline Thermal scarification (hot water $\left.70^{\circ} \mathrm{C}\right)-5^{\prime}$ & $2 \mathrm{~b}$ & $0.03 \mathrm{~b}$ & $2 \mathrm{~b}$ \\
\hline Thermal scarification (hot water $\left.70^{\circ} \mathrm{C}\right)-10^{\prime}$ & $0 \mathrm{~b}$ & $0.00 \mathrm{~b}$ & $0 \mathrm{~b}$ \\
\hline Coefficient of variation $(\%)$ & 30.60 & 6.92 & 32.72 \\
\hline
\end{tabular}

Means followed by the same letter in the column do not differ by the Scott-Knott test at 0.01 probability. 
For overcoming physical dormancy, mechanical scarification initially proved to be a promising treatment, since the first germination was observed in this treatment on day 12 . However, the seeds of this group in the following days suffered a greater predisposition to the infestation of microorganisms, possibly endophytic fungi, such manifestation may have been one of the causes of the disuniformity presented in germination, leading with time the paralysis of the process and in some cases death of seeds (data not shown). Figure 1 shows the heterogeneity of $D$. bicolor seed germination.
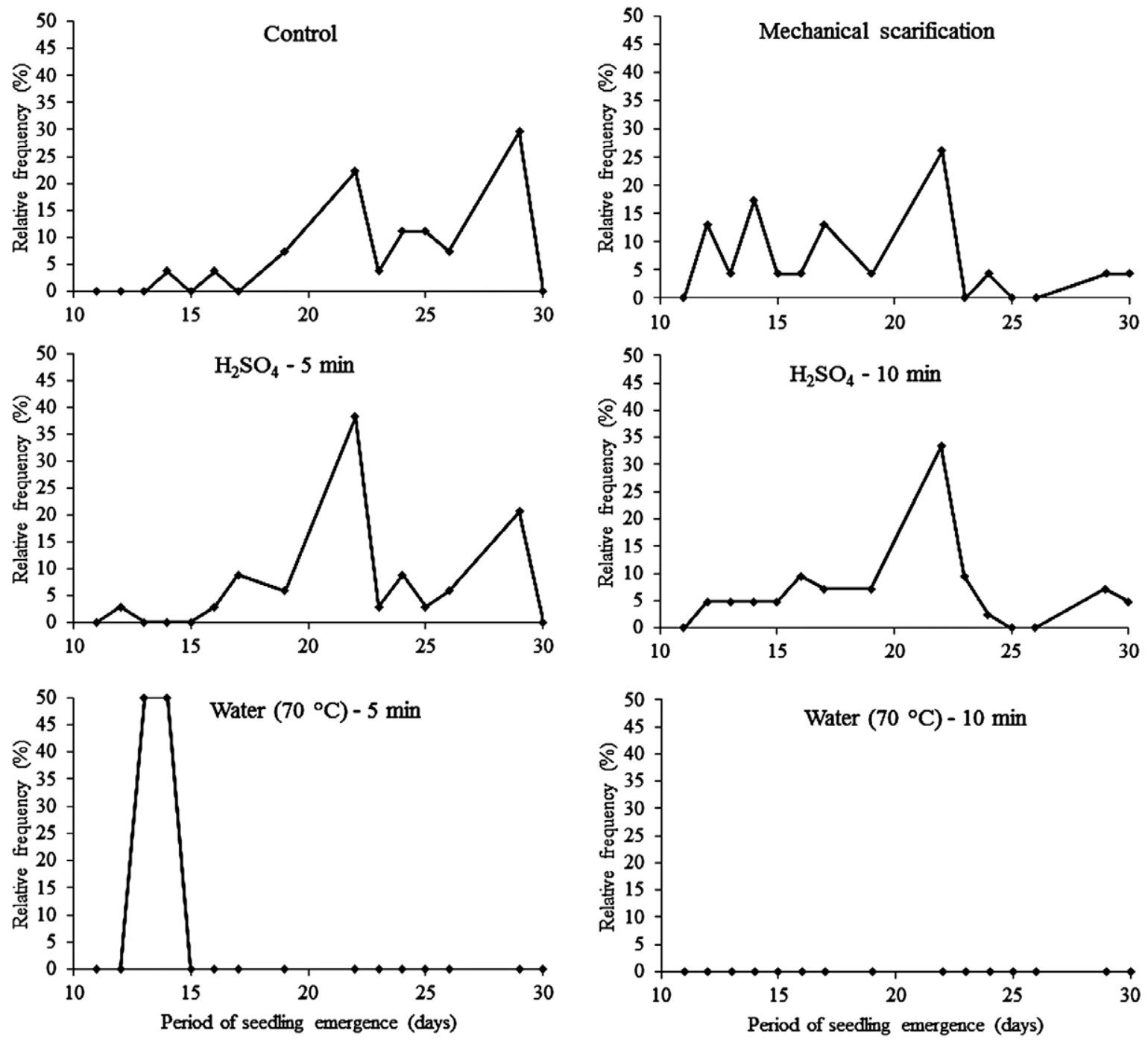

Figure 1. Distribution of the germination frequency of Dietes bicolor seeds submitted to different dormancy breaking treatments.

The scarifications made with acid showed greater homogeneity of the germination process evidencing a single peak of germination frequency near 20 days after sowing (Figure 1). However, we can observe higher amounts of germination peaks with the stratification time of five minutes at relative frequency, inferring a lower homogenization of the germination process when compared to the scarification done at ten minutes.

The ten-minute chemical scarification showed to be the most stable among the treatments in its frequency of germination over the days (Figure 1), besides being the first treatment after mechanical stratification to have the anticipation of the first expected germination (Table 2), despite having obtained a low frequency in the first days we can observe greater stability when compared to the other trials.
It can be seen that the distribution of the relative frequency of the treatments presented a polymodal behavior, highlighting among them the treatment with 10 minutes acid, in which this effect was attenuated inferring more concentrated germination and in a shorter time. Although the thermal treatment $70{ }^{\circ} \mathrm{C}$ of 5 minutes had a unimodal visual behavior, its germination peak has the origin far from the axes, so it owes too much time, besides low germination (2\%) (Table 2 and Figure 1). The treatment done with thermal scarification of $70{ }^{\circ} \mathrm{C}$ for 10 minutes remained at zero according to the relative frequency formula during the entire time of the experiment since no germination was obtained (Figure 1).

According to the daily germination graph (Figure 2), it was verified that on the 20th day most of the treatments 
accounted for $50 \%$ of their final germination, so this day can be considered the first count. Such facts were corroborated by Souza et al. (2020) on treatments for overcoming dormancy of Spodias dulcis, by Jeromini et al. (2020) on treatments for overcoming dormancy of Bauhinia scandens and Gama et al. (2019) in determining how to conduct the germination test of Carthamus tinctorius.

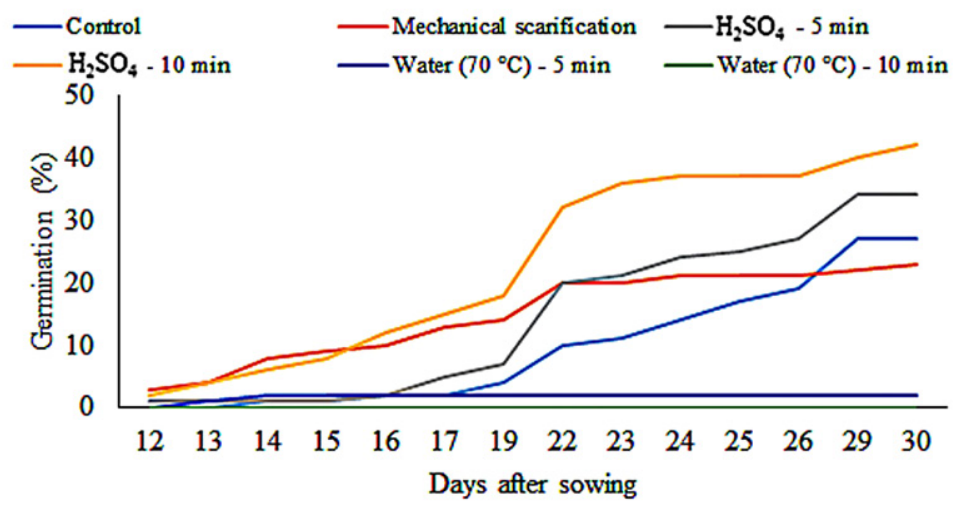

Figure 2. Percentage of accumulated daily germination of Dietes bicolor seeds submitted to different dormancy breaking treatments.

The acid treatment in 10 minutes is promising, but not enough to overcome dormancy. These results suggest the occurrence of combined dormancy in D. bicolor seeds, a characteristic also reported in other Iridaceae species such as Iris Tenax (Jones and Kaye, 2014) and Belamcanda chinensis (Silva et al., 2017; Silva et al., 2018).

To analyze the occurrence of morpho-physiological dormancy of $D$. bicolor seeds, stratification treatments were evaluated. However, the alternation of temperatures in different periods did not show differences concerning the control treatment regarding the germination percentage and germination speed index (Table 3), although higher values were observed in the stratification treatment with hot temperatures for 2 weeks (30\% and 0.24$)$. Moreover, only this treatment showed a difference in the first count (13\%) compared to the other treatments applied (Table 3 ). According to Carta et al. (2014), high temperatures in some species of the genus Crocus (Iridaceae) are essential for the emergence and development of the radicle, thus indicating the need for summer temperatures to break physiological dormancy. Furthermore, Goldblatt et al. (2008a) report that the prime time for flower formation and sexual reproduction in this family is during warmer seasons, a period that tends to have elevations in the climate, thus culminating in seed dispersal in times of higher temperatures.

Table 3. Germination (G), germination speed index (GSI), and first count (FC) of Dietes bicolor seeds submitted to temperature stratification treatments with hot $(\mathrm{HT})$ and cold $(\mathrm{CT})$ temperatures.

\begin{tabular}{|c|c|c|c|}
\hline Treatments & G (\%) & GSI & FC (\%) \\
\hline Contol & 22 & 0.11 & 0 \\
\hline 1 week CT & $20 \mathrm{a}$ & $0.11 \mathrm{a}$ & $0 \mathrm{a}$ \\
\hline 1 week HT & $20 \mathrm{a}$ & $0.13 \mathrm{a}$ & $0 \mathrm{a}$ \\
\hline 1 week HT + 1 week CT. & $13 \mathrm{a}$ & $0.11 \mathrm{a}$ & $10 \mathrm{a}$ \\
\hline 2 weeks CT & $18 \mathrm{a}$ & $0.11 \mathrm{a}$ & $0 \mathrm{a}$ \\
\hline 2 weeks HT & $30 \mathrm{a}$ & $0.24 \mathrm{a}$ & $13^{*} \mathrm{a}$ \\
\hline 1 week HT + 2 weeks CT & $12 \mathrm{a}$ & $0.09 \mathrm{a}$ & $3 \mathrm{a}$ \\
\hline 2 weeks HT + 1 week CT & $28 \mathrm{a}$ & $0.20 \mathrm{a}$ & $7 \mathrm{a}$ \\
\hline
\end{tabular}

*Treatments that statistically differ from control by Dunnett's test at 0.01 probability.

Means followed by the same letter vertically do not differ statistically from each other by the Scott-Knott test at 0.05 probability. 
In general, it can be inferred that in the stratification at elevated temperatures occurs a greater predisposition to germination in a shorter time, and similarly, scarification in cold environments incurs in lower rates of germination speed. In this sense, the treatment of 2 weeks HT, among all treatments, stood out because, in addition to obtaining $30 \%$ in its germination rate, it was the test that obtained in its repetitions a similar number of development (Figure 3), besides having a difference in the first count of germination (Table 3).

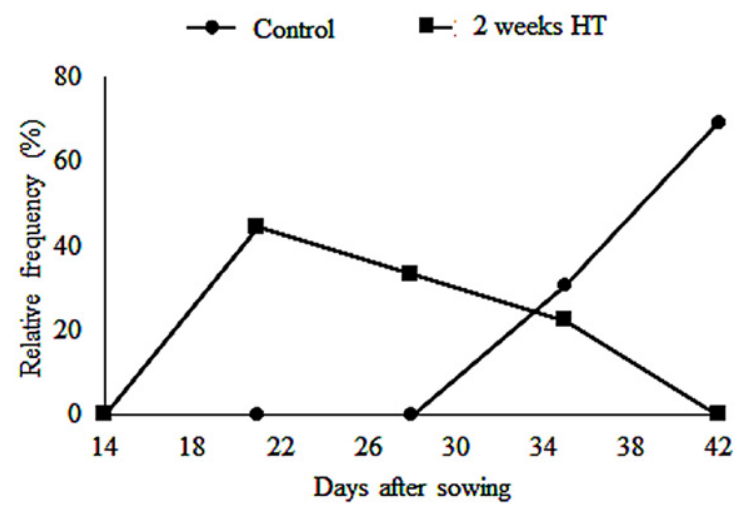

Figure 3. Distribution of the germination frequency of Dietes bicolor seeds submitted to two weeks of hot temperature $\left(20-30^{\circ} \mathrm{C}\right)$ stratification in comparison to the control.

Despite the higher values obtained with warm stratification, the results suggest that probably the seeds of this lot showed combined dormancy. Future studies are necessary to evaluate the use of longer times and/or stress conditions to optimize the stratification processes and, consequently, the germination of $D$. bicolor seeds.

\section{Conclusions}

The seeds of D. bicolor presented characteristics that suggest the occurrence of physical and morphophysiological dormancy. The ten-minute sulfuric acid treatment preliminarily equaled mechanical scarification in terms of initial germination and outperformed it in terms of uniformity. However, only the first count of this treatment differed from the control. Stratification at elevated temperatures provided greater uniformity in the germination of $D$. bicolor that was not possible with acid alone. The results presented in this study contribute to the optimization of pre-germination practices for this important ornamental species.

\section{Acknowledgements}

This study was financed in part by the Coordenação de Aperfeiçoamento de Pessoal de Nível Superior - Brazil (CAPES) - Finance Code 001 and the Conselho Nacional de Desenvolvimento Científico e Tecnológico - Brasil (Scientific Initiation Scholarship-CNPq).

\section{Author Contribution}

TRRB: performed the experiments, analyzed the experimental data and wrote the manuscript; MLS: reviewing literature and contributed to the writing of the manuscript; GZS: participated in all of experiments, coordinated the data analysis and contributed to the writing of the manuscript; DIR: designed the study, reviewing literature and wrote the manuscript.

\section{References}

AYOUB, I.M.; KORINEK, M.; TSONG-LONG, H.; BINGHUNG, C.; FANG-RONG C.; EL-SHAZLY, M.; SINGAB, A.N.B. Probing the antiallergic and anti-inflammatory activity of biflavonoids and dihydroflavonols from Dietes bicolor. Journal of Natural Products, v.81, p.243-253, 2018. https://doi.org/10.1021/acs.jnatprod.7b00476

BASKIN, C.C.; BASKIN, J.M. Seeds: ecology, biogeography, and evolution of dormancy and germination. $2^{\mathrm{a}}$ ed. Lexington: Academic Press, 2014. 1600p. https://doi.org/10.1016/C2013-0-00597-X

BRASIL. Ministério daAgricultura, Pecuária e Abastecimento. Regras para Análise de Sementes (RAS). Brasília: Mapa/ Assessoria de Comunicação Social, 2009. p.398.

CARTA, A.; HANSON, S.; MÜLlER, J.V. Plant regeneration from seeds responds to phylogenetic relatedness and local adaptation in Mediterranean Romulea (Iridaceae) species. Ecology and Evolution, v.6, n.12, p.4166-4178, 2016. https://doi.org/10.1002/ece3.2150

CARTA, A.; PROBERT, R.; MORETTI, M.; PERUZZI, L.; BEDINI, G. Seed dormancy and germination in three Crocus ser. Verni species (Iridaceae): implications for evolution of dormancy within the genus. Plant Biology, v.16, n.6, p.1065-1074, 2014. https://doi.org/10.1111/plb.12168 
FLOSS JÚNIOR, O.; SILVA, T.B.M., DEMARTELAERE, A.C.F.; MEDEIROS, J.G.F.; PRESTON, H.A.F.; FEITOSA, S.S.; FERREIRA, A.S.; CÂMARA, Y.P. Uso de substratos alternativos no sistema hidropônico e a influência na produção de mudas de Lactuca sativa L. Brazilian Journal of Development, v.6, n.10, p.7772877743, 2020. https://doi.org/10.34117/bjdv6n10-268

GAMA, G.F.; MACHADO, C.G.; SILVA, G.Z.; MORAES, A.L.C.; SILVA, A.A.S.; SILVA, I.M.H.L. Substrates and duration for conducting the safflower seed germination test. Científica, v.47, p.426-433, 2019. http://dx.doi. org/10.15361/1984-5529.2019v47n4p426-433

GOLDBLATT, P.; MANNING, J.C. The Iris family. Natural history and classification. London: Timber Press, 2008a. 336p.

GOLDBLATT, P.; RODRIGUEZ, A.; POWELL, M.P.; DAVIES, T.J.; MANNING, J.C.; VAN DER BANK, M.; SAVOLAINEN V. Iridaceae 'Out of Australasia'? phylogeny, biogeography, and divergence time based on plastidDNAsequences. Systematic Botany, v.33, n.3, p.495508, 2008b. https://doi.org/10.1600/036364408785679806

HAJYZADEH, M.; YILDIRIM, M.U.; MOKHTARZADEH, S.; SARIHAN, E.O.; KHAWAR, K.M. Breaking of seed dormancy in Iris suaveolens Boiss. et Reuter under in vitro conditions. Acta Scientiarum Polonorum Hortorum, v.18, n.4, p.15-24, 2019. https:// doi.org/10.24326/asphc.2019.4.2

JEROMINI, T.S.; PEREIRA, T.S.; MARTINS, C.C.; SILVA, G.Z. Overcoming dormancy in Bauhinia scandens seeds. Semina: Ciências Agrárias, v.41, n.4, p. 11891198, 2020. https://doi.org/ 10.5433/1679-0359.2020v41n $4 \mathrm{p} 1189$.

JONES, K.D.; KAYE, T.N. Factors influencing germination of a functionally important grassland plant, Iris tenax. PLoS ONE, p.e90084, 2014. https://doi.org/10.1371/ journal.pone.0090084

JUNQUEIRA, A.H.; PEETZ, M.S. Brazilian consumption of flowers and ornamental plants: habits, practices and trends. Ornamental Horticulture, v.23, n.2, p.178-184, 2017. https://doi.org/10.14295/oh.v23i2.1070

KILDISHEVA, O.A.; DIXON, K.W.; SILVEIRA, F.A.O.; CHAPMAN, T.; DI SACCO,A.; MONDONI,A.; TURNER, S.R.; CROSS, A.T.; Dormancy and germination: making every seed count in restoration. Restoration Ecology, v.28, n.S3, p.S256-S265, 2020. https://doi.org/10.1111/ rec. 13140
MAGUIRE, J.D. Speed of germination-aid in selection and evaluation for seedling emergence and vigor. Crop Science, v.2, n.2, p.176-177, 1962. https://doi.org/10.2135/ cropsci1962.0011183X000200020033x

MENEGAES, J.F.; NISHIJIMA, T.; BACKES, F.A.A.L.; BENETTI, C.C. Práticas de ajardinamento em espaços de convivência em comunidades rurais como instrumento de Educação Ambiental. Research, Society and Development, v.9, n.11, p.1-19, 2020.

SILVA, G.H.; BALDINI, L.S.; TOMAZ, C.A.; ROSSI, R. F.; NAKAGAWA, J. Germination temperatures and treatments to overcome dormancy in Belamcanda chinensis seeds. Pesquisa Agropecuária Tropical, v.47, n.4, p.377-383, 2017. https://doi.org/10.1590/1983$40632017 \mathrm{v} 4749059$

SILVA, G.H.; BALDINI, L.S.; TOMAZ, C.A.; ROSSI, R. F.; NAKAGAWA, J. Germination of stored Belamcanda chinensis (L.) DC seeds. Ornamental Horticulture, v.24, n.2, p.149-154, 2018. https://doi.org/10.14295/ oh.v24i2.1176

SILVA, L.A.S.; COSTA, A.O.; BATISTA, D.S.; SILVA, M.L.; NETTO, A.P.C; ROCHA, D.I. Exogenous gibberellin and cytokinin in a novel system for in vitro germination and development of African iris (Dietes bicolor). Revista Ceres, v.67, n.5, p.402-409, 2020. https://doi. org/10.1590/0034-737X202067050008

SOUZA, P.H.M.; RAGAGNIN, A.L.S.L.; RIBEIRO, R.C.; SILVA, G.Z.; ROCHA, D.I.; SILVA, D.F.P. Dormancy overcoming in seeds of cajá-manga (Spondias dulcis). Comunicata Scientiae, v.11, p.e3341, 2020. https://doi.org/10.14295/cs.v11i0.3341

SCHMIDT, P.M.S.; NUNES, U.R.; BACKES, F.A.A.L.; SANGOI, P.R.S.; FAGUNDES, L.K.; FERNANDES, T.S.; DALCIN, J.S. Métodos de superação de dormência em sementes de maxixe. Revista Cultura Agronômica, v.26, n.1, p.53-60, 2017. https://doi.org/10.32929/24468355.2017v26n1p53-60.

VAN RIJSWICK, C. World Floriculture Map 2016: Equator Countries Gathering Speed. Rabobank Relatory. nov. 2016 Available at <https://research.rabobank.com/far/en/ sectors/regional-food-agri/world_floriculture_map_2016. html $>$ Acessed September 19, $20 \overline{20}$. 